\title{
Training the industrial and organisational psychologist as counsellor: Are we doing enough?
}

\author{
Authors: \\ Hanri Barkhuizen ${ }^{1}$ \\ Lené I. Jorgensen ${ }^{1}$ \\ Lizelle Brink ${ }^{1}$

\begin{abstract}
Affiliations: Sciences, School of Human Resource Management Sciences, North-West University, Potchefstroom Campus, South Africa
\end{abstract} \\ ${ }^{1}$ WorkWell, Research Unit for \\ Economic and Management

\section{Correspondence to:} \\ Lené Jorgensen \\ Email: \\ 10094598@nwu.ac.za \\ Postal address: \\ Private Bag X6001, \\ Potchefstroom 2520, \\ South Africa \\ Dates: \\ Received: 22 Jan. 2014 \\ Accepted: 13 Apr. 2015 \\ Published: 02 June 2015 \\ How to cite this article: \\ Barkhuizen, H., Jorgensen, \\ L.I. \& Brink, L., 2015, \\ 'Training the industrial and \\ organisational psychologist \\ as counsellor: Are we doing \\ enough?', Acta Commercii \\ 15(1), Art. \#253, 12 pages. \\ http://dx.doi.org/10.4102/ \\ ac.v15i1.253 \\ Copyright: \\ (C) 2015. The Authors. \\ Licensee: AOSIS \\ OpenJournals. This work is \\ licensed under the Creative \\ Commons Attribution \\ License.
}

Read online:

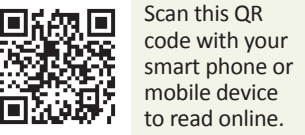

Orientation: Industrial and organisational (I-O) psychologists are responsible for workplace counselling. Workplace counselling requires specific skills and training for the I-O psychologist.

Research purpose: The main aim of the study was to explore the role of training the I-O psychologist as workplace counsellor.

Motivation for the study: Studies show that the I-O psychologist does not feel adequately prepared for their role as workplace counsellor. It is important to explore which skills and training are needed to equip the I-O psychologist as counsellor.

Research approach, design and method: A qualitative research design with convenience and snowball sampling was used to identify I-O psychologists $(n=22)$ from different business sectors in Gauteng and North-West. Semi-structured interviews were conducted to gather data and content analysis was utilised to extract themes and sub-themes from the results.

Main findings: The findings showed that the participants know about the process of counselling, but they did not feel adequately prepared for their role as workplace counsellors. From the findings, recommendations for the training of future I-O psychologists are made.

Practical implications: This study adds to the knowledge about ensuring that the I-O psychologist is equipped during their training for the workplace to address the counselling needs of employees in the workplace in South Africa.

Contribution/value-add: This study contributes towards ensuring that the I-O psychologist is sufficiently prepared for their role as workplace counsellor by making knowledge available regarding the skills required by $\mathrm{I}-\mathrm{O}$ psychologists to be applied in practice.

Keywords: Industrial-organisational (I-O) psychologist; Counsellor; Skills and competencies; Qualitative research; Training

\section{Introduction}

Industrial and organisational (I-O) psychology was traditionally, and remains to be, profoundly influenced by clinical, counselling, educational and cognitive psychology. Strümpfer (2007) notes that the gap existing between psychology and I-O psychology should be reversed, observing that I-O psychology is in effect an extension of psychology, or a sub-profession of psychology (Van Vuuren 2010). Rothmann and Cilliers (2007) reached the conclusion that there is only one psychology, with different fields of application. In recent years, a large degree of confusion and overlap has developed relating to the nature and scope of I-O psychology (Barnard \& Fourie 2007). Barnard and Fourie (2007) state that the need has therefore arisen for the I-O psychologist to clarify the role and contributions of the field of I-O psychology. Since the 20th century, psychologists have recognised the necessity to classify the practice and resolve issues such as education, training and licensure, which define their profession. Johnson and Kaslow (2014) believe that this attempt to establish a legitimate identity for professional psychology was made to protect the general public from those who would allege the title of psychologist without the proper training.

This article aims to explore the role of the I-O psychologist as counsellor; therefore, the objectives of this study were:

- To explore what counselling skills are required by practising I-O psychologists.

- To determine what type of counselling training I-O psychologists received during their academic training.

- To determine whether practising I-O psychologists received additional training in counselling skills.

- To make recommendations for the training curriculum of I-O psychology students regarding counselling skills. 


\section{The industrial-organisational psychology profession}

I-O psychologists in South Africa register with a licensing body, namely the Professional Board for Psychology, within the Health Professions Council of South Africa (HPCSA) (South Africa Department of Health 2012). The practical contributions of the I-O psychologist relate to training and development, change management, psychometric testing, labour relations, organisational development, selection and placement, human resource management and counselling (Bergh 2011; Pienaar \& Roodt 2001). Moreover, the discipline of I-O psychology has expanded from initially being problem focused to taking on a broader domain of interest that comprises the following subfields: personnel psychology, organisational psychology, career psychology and psychometrics (Barnard \& Fourie 2007; Bergh 2011; Van Vuuren 2006; 2010).

It can be concluded that I-O psychology is the scientific study of humans within their work environment, which includes the application of psychological principles to the work environment (Bergh 2011; Landy \& Conte 2004; Rothmann \& Cilliers 2007; Van Vuuren 2010).

\section{The industrial-organisational psychologist as counsellor}

Johnson and Kaslow (2014) concede that the application and usefulness of psychological principles have been acknowledged in business since the 20th century. As far back as 1979, Cristiani and Cristiani noted that the need for counsellors in the business industry has been evident. Offering counselling services could change the way managers and other staff members think about emotional difficulties and personal problems, which, in turn, change the discourse of the workplace (McLeod \& Henderson 2003; McLeod \& McLeod 2011). Strümpfer (2007) emphasises that the responsibility lies with the I-O psychologist to attempt to resolve these problems. Bergh (2011) states that the tasks of I-O psychologists as workplace counsellors relate to the nurturing of well-adjusted employees and their optimal growth and wellness.

The psychological profession is affected by social, political and economic factors, as stated by Johnson and Kaslow (2014). They further indicate that armed conflict results in psychological suffering, which increases awareness of mental illness and people seeking mental health treatment, in the end resulting in the ongoing need for and relevance of the psychological profession.

Addressing the wellness of employees implies that the boundaries within which the I-O psychologist functions are extended beyond the organisation. External forces to the workplace, such as Human Immunodeficiency Virus (HIV), Acquired Immunodeficiency Syndrome (AIDS) and traumatic incidents (Van Vuuren 2010) lie beyond the workplace, yet greatly affect employees. In relation, employee assistance programmes (EAP) are implemented in organisations to improve employee wellness and to address workplace problems (Azaroff et al. 2010). However, in a study done by Barnard and Fourie (2007), organisations indicate a need for more proactive strategies to ensure that individuals are healthy. One way of accomplishing the abovementioned is through workplace counselling.

\section{Counselling skills and competencies}

Pienaar and Roodt predicted in 2001 that the I-O psychologist's role will continue to develop into that of a counsellor. Moreover, I-O psychologists should be equipped with skills pertaining to knowledge of empathy, communication and listening skills (Pienaar \& Roodt 2001). Johnson and Kaslow (2014) believe that facilitative interpersonal skills are required, referring to an individual's ability to effectively and accurately communicate and interpret messages as well as the ability to persuade others in helpful ways. Research done in 1987 revealed that clinical and counselling skills, including effective listening and interviewing skills, were viewed as most essential for I-O psychologists (Carducci et al. 1987). More recently, researchers indicate reflecting, paraphrasing, probing and referral to be basic skills necessary for counsellors (Culley \& Bond 2004; Ivey 2013; McLeod 2007). The helping model developed by Carkhuff (2008) can be utilised effectively in a workplace situation and can also be utilised to train undergraduates interested in the helping profession. Even though problems related to people in the workplace provide industrial psychology with the reason for its existence (Landy \& Conte 2004; Van Vuuren 2010), most graduate programmes in the behavioural sciences do not include basic counselling courses in their curriculum (Carducci et al. 1987). Byrne et al. (2014) strongly suggest that the training curriculum for I-O psychology should include extensive coverage of the breadth of psychology.

\section{Counselling training}

Research indicates that when psychologists started working in applied settings such as government, education and health care institutions, during the 20th century, the importance of initiatives to conceptualise the training and education of professional psychologists was realised (Johnson \& Kaslow 2014). Despite evolution over the years, Barnard and Fourie (2007) question whether the curriculum of the I-O psychology training courses fully addresses all of the educational, training, developmental and skills needs of I-O psychologists. Against this ever-changing environment of psychological services, education and training in professional psychology should be equally relevant (Johnson \& Kaslow 2014). When studying counselling skills for I-O psychologists in South Africa, it is important to consider what skills are necessary to include in a training programme. Egan (2009) suggests that a professional curriculum aimed at training helpers should include both knowledge and skills. Egan (2009:27) further states that professional helping curricula 'enable helpers to understand and work with their clients as effectively as possible in 
the service of a problem management and opportunity development'. Byrne et al. (2014) suggest that I-O psychology students' training should include training in the broad spectrum of psychology, including cognitive-affective and emotional bases of behaviour, as well as personality theory, human development and abnormal psychology. Therefore, nurturing the development of theoretical knowledge is often considered to be a key priority for training in professional psychology (Johnson \& Kaslow 2014).

Young (2009) suggests that a training curriculum for counselling skills should include relationship building, knowledge of human development, application of psychological theories and assessment. Literature on the training aimed at developing intrapersonal and interpersonal awareness and skills for helpers shows that knowledge about a helping model (Carkhuff 2008) and micro-skills should be combined (Ivey 2013) and knowledge regarding individuals and groups should be included (Cilliers 2000; Du Preez \& Jorgensen 2012; Rothmann \& Van Aardt 2002).

In conclusion, the I-O psychologist as counsellor can make use of counselling skills and competencies to assist employees, which, in turn, also benefits organisations. One question that remains is whether the I-O psychologist currently receives training in the necessary skills, competencies and training to fulfil this role.

\section{Methodology}

The research was qualitative in nature and a phenomenological approach was utilised. Qualitative research provides researchers with the opportunity to collect rich data regarding a specific phenomenon, which enables the researchers to form an understanding of the specific phenomenon under study (Niewenhuis 2010). The aim of the phenomenological approach is to understand and interpret the meanings that participants attach to everyday life as they experience it (De Vos et al. 2005). Phenomenological research therefore enables researchers to understand and give dense descriptions of a phenomenon that individuals experience in their natural setting (Gray 2004). When employing the phenomenological approach, the researcher experiences the world by setting aside their preconceived theories and ideas (Frost 2011). The researchers of this study therefore aimed to understand how industrial psychologists experienced being trained as workplace counsellors during their academic training.

Furthermore, the paradigmatic viewpoint that the researchers followed in this research study was that of interpretivism. Interpretivism states that there is no single accepted reality, but that individuals, in order to make sense of the world in which they live, construct their own reality and, therefore, many intangible and subjective realities exist (Wagner, Kawulich \& Garner 2012). Therefore, individuals in this study may differ with regard to their reality, specifically with regard to their experience of being trained as workplace counsellors during their master's degree training.
With regard to the research strategy of this research study, a case study strategy was employed. Case studies are useful when the researcher wants to study events or phenomena over which they have no control (Gray 2004). By employing a case study strategy, the researcher is able to answer how and why questions relating to the specific event or phenomenon they experience, which, in this study, is industrial psychologists' experience of being trained as workplace counsellors during their master's degree training (Gray 2004).

\section{Participants and sampling}

Research was conducted amongst I-O psychologists $(n=22)$ practising across different sectors in North-West and Gauteng in South Africa. Access to the group of participants was obtained by contacting the participants from a list containing the names of all registered I-O psychologists from the HPCSA. When participants displayed an interest in participating in the study, information regarding the study and an informed consent form stating that the study was voluntary were provided.

A combination of convenience and snowball sampling was utilised. The inclusion criteria for the study were that practising I-O psychologists must be registered with the HPCSA in order to be contacted for an interview. The sample size was determined by the number of participants accessible and willing to participate in the study; interviews were conducted until data saturation was attained. The majority of the participants were female (68\%), aged 26 to 30 years. The participants were mostly white people (82\%), Afrikaans speaking (77\%) and had obtained an MCom degree in Industrial Psychology between 2001 and 2006. Participants were generally from North-West (59\%), whilst $41 \%$ of the participants were from Gauteng.

\section{Data collection and analysis}

Semi-structured interviews were used to collect data. An interview guide was used to provide information referring to the estimated duration of the interview, the assurance of confidentiality, an explanation of the voluntary nature of the study and an explanation of the use of the voice recorder. Once it was established that the participants were exposed to counselling situations in their workplace, the following interview questions were asked:

1. What kind of counselling skills are you required to have?

2. What type of counselling training did you receive during your master's training?

3. Did you receive any additional training?

4. What suggestions can you make in terms of the curriculum of I-O psychology students regarding counselling skills?

A pilot study $(n=3)$ was conducted with three participants in order to ensure that questions were correctly understood by participants. Participants were also requested to complete a biographical questionnaire. 


\section{Recording of data}

Permission was obtained to use the voice recorder by explaining its purpose before conducting the interviews. The interviews were transcribed into an Excel spreadsheet after all the interviews had been conducted. Once this process had been completed, the transcripts of the interviews were compared to the original voice recordings in order to ensure that no information was overlooked.

\section{Data analysis}

Content analysis was used to evaluate the data. Content analysis consists of a process in which data is examined from multiple angles with the aim of identifying key findings that allow the researcher to gain a better understanding and interpretation of the raw data (Maree 2007). Numerous co-coders who were employed in the field of industrial psychology assisted the researchers with the content analysis, which also increased the reliability of the results.

The following six steps, as outlined by Cresswell (2009), were utilised to analyse the data by making use of content analysis:

1. Data were collected; thereafter, the data were organised, prepared and transcribed verbatim.

2. The researchers read through all the transcribed data in order to understand and obtain a general feeling of the information collected. The researchers also freed the data from redundant and irrelevant information, thereby excluding these from data analysis.

3. The researcher utilised a coding process during this step. The transcribed data divided into categories that were named with relevant terminology. The co-coders assisted the researchers during this step.

4. Categories, themes and sub-themes were described by continuing to make use of the coding procedure. Rigorous data analysis was employed before extracting themes and sub-themes. Themes and sub-themes that the researchers struggled with were discussed with the co-coders.

5. The researchers made a decision as to the manner in which the categories and themes will be presented. Subthemes and quotations were used to illustrate categories and themes. Categories, themes and sub-themes were checked by the co-coders to ensure that the researchers give a truthful representation thereof.

6. The final step involved the interpretation of the significance of the data collected. The researchers did not only report the results of the study, but also made use of relevant literature to support and explain the findings of this research.

\section{Trustworthiness}

To ensure the trustworthiness of the results, the researcher made use of techniques such as confirmability, credibility, dependability and transferability.

\section{Confirmability}

During the research process, the researchers remained free from bias by not allowing their own perspectives and motives to influence the data (Botma et al. 2010). The researchers therefore ensured that they remained objective throughout the entirety of this study by truthfully capturing the experiences of the participants.

\section{Dependability}

The researchers ensured dependability of the results by clearly and densely describing the research methodology (Botma et al. 2010). This was done by clearly documenting all the phases of this research process, especially regarding the write-up of the methodology section of this research.

\section{Credibility}

The researchers ensured that they reported the findings of the research truthfully, just as they were experienced by the participants of this study (Botma et al. 2010). The researcher ensured that she truthfully reported the various ways in which a counselling training programme was experienced by participants.

\section{Transferability}

Transferability ensures that the findings of a research study can be applied to other contexts; therefore, the researchers provided a clear and dense description of the context and setting of the data (Botma et al. 2010).

Next, the findings of the study will be reported, followed by a discussion of the findings.

\section{Findings}

The results of the study are arranged into various categories, themes and sub-themes, along with quotations supporting the findings. The frequencies of each theme are provided in brackets (the frequencies refer to the number of times the particular theme was mentioned and not the number of participants who mentioned the theme). Figure 1 provides a summary of the categories with the main themes.

\section{Category 1: Counselling skills required by I-O psychologists}

In this category, participants were asked to elaborate on the counselling skills and competencies utilised during counselling, which are reported in Table 1.

From Table 1, the following themes and sub-themes materialised:

- Facilitation skills.

- Effective communication.

- Non-verbal communication.

- Probing.

- Questioning. 
- Process knowledge.

- Referral.

- Interpersonal skills.

- Empathy.

- Remain neutral.

- Remain objective.

\section{Facilitation skills}

Participants perceive knowledge of the facilitation process during counselling as important. Facilitation was viewed as assisting the client to reach a point where self-insight is obtained by utilising a non-directive approach. Building rapport was mentioned as an important prerequisite for a counselling process in order for the client to feel comfortable to disclose confidential information. The safety of the environment in which the counselling takes place was also indicated by the participants as an important aspect to consider.

\section{Effective communication}

Most participants indicated listening as a necessary skill in the counselling process, since this skill also refers to the ability to listen actively to what the clients are saying. Apart from mentioning what skills participants used during counselling, some participants also referred to ineffective communication, which should be avoided during counselling. Participants warned against giving clients advice and that the counsellor should avoid interrupting the client.

\section{Non-verbal communication}

Participants viewed non-verbal communication as an important skill in counselling. It was reported that it is important to make eye contact with clients and to pay attention to the non-verbal communication of the clients such as their body language.

\section{Probing}

Some of the participants mentioned that probing is a skill that they use during counselling in order to obtain more information from the client.

\section{Questioning}

Some participants mentioned questioning as a necessary skill in the counselling process; this relates to pursuing a suitable line of questioning.

\section{Process knowledge}

Participants mentioned that the use of a counselling process or model during the counselling process is helpful. It was

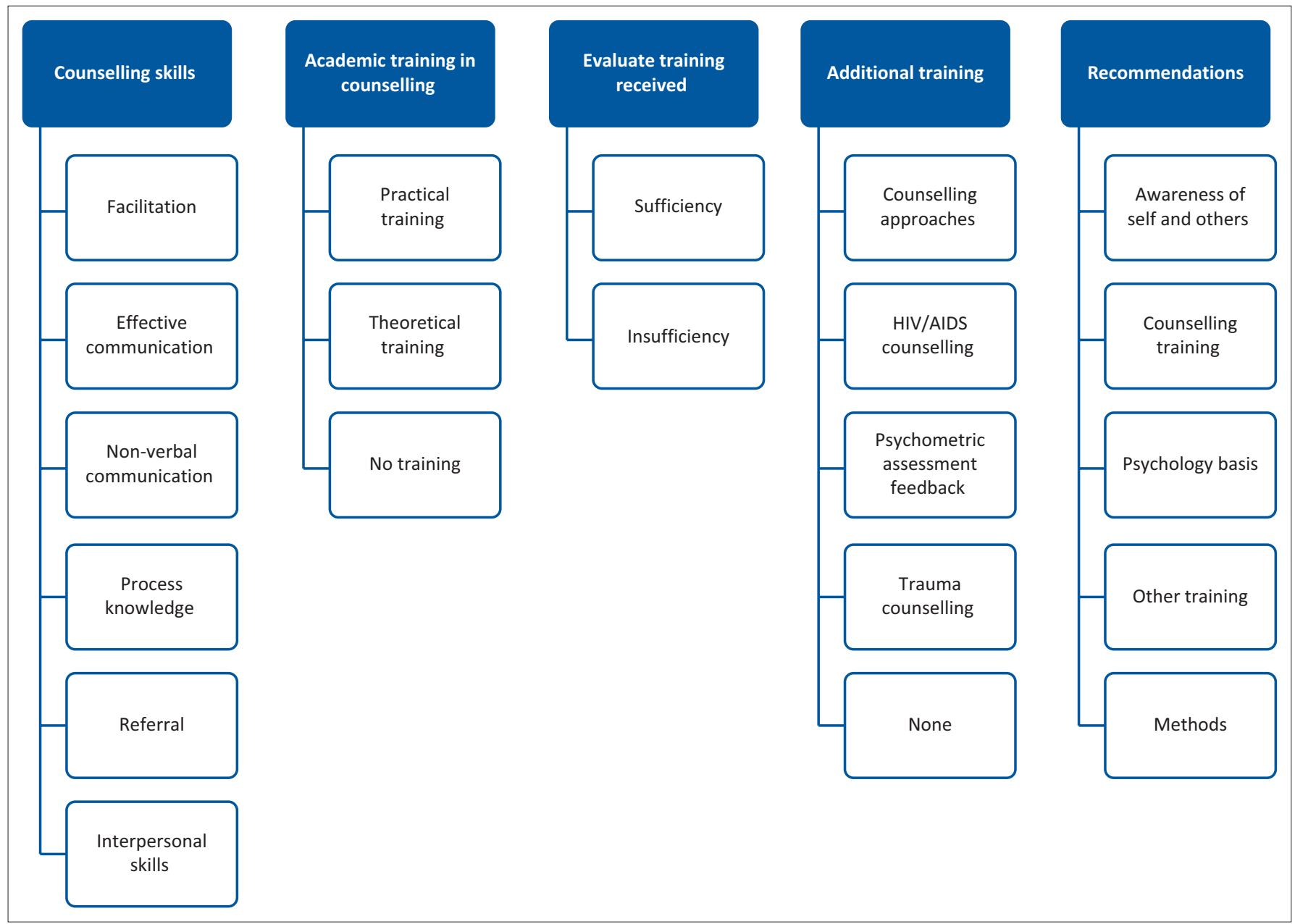

FIGURE 1: An illustration of the categories and themes of the findings. 
TABLE 1: Counselling skills required by I-O psychologists.

\begin{tabular}{|c|c|c|}
\hline Theme & Sub-theme & Response \\
\hline \multirow[t]{11}{*}{ Facilitation skills (23) } & Achieving insight & 'And to offer that guidance, to allow them to reach that "ah-ha!" moment themselves.' \\
\hline & Development & 'To enter into a developmental programme ... to me, it is much about development.' \\
\hline & Providing feedback & 'And I will also sometimes give them honest feedback, but I would rather do it at a later stage.' \\
\hline & Non-directive approach & 'Knowing not to give advice, ever!' \\
\hline & Building rapport & $\begin{array}{l}\text { 'I think, for me, personally, trying to build a good relationship with the individuals. So the rapport- } \\
\text { building is critical, especially then if you have an individual that is quite negative upfront.' }\end{array}$ \\
\hline & Client centred & $\begin{array}{l}\text { 'I want them to be satisfied ... and I want them to feel that it had helped. ... I ask people upfront what } \\
\text { their expectations are.' }\end{array}$ \\
\hline & Encourage & $\begin{array}{l}\text { 'The theoretical aspects are how you carry yourself, how you concentrate to really pick up things that } \\
\text { people say, and how you encourage them to open up more.' }\end{array}$ \\
\hline & Initiate disclosure & 'To get this person to talk as much as possible about the situation.' \\
\hline & Make clients feel comfortable & $\begin{array}{l}\text { 'For me, the most important thing is that people are comfortable with me, and I want them to leave } \\
\text { feeling satisfied.' }\end{array}$ \\
\hline & Providing a safe environment & $\begin{array}{l}\text { 'To provide a safe environment. People sometimes just want an ear, so it's important to me that they } \\
\text { will know that it is confidential; that they are still in control of the situation.' }\end{array}$ \\
\hline & Set clear boundaries from the start & 'Also to set your boundaries very clearly with some individuals.' \\
\hline \multirow{4}{*}{ Effective communication (27) } & Active listening & 'To listen from multiple angles to obtain good collateral information, in order to cross-confirm.' \\
\hline & $\begin{array}{l}\text { Avoid giving advice; avoid } \\
\text { interrupting the client }\end{array}$ & $\begin{array}{l}\text { 'That there is no miss-communication ... or that one is too quick to interrupt people and try and give } \\
\text { immediate advice, rather than just finishing listening.' }\end{array}$ \\
\hline & Probing & 'I think most likely just probe more than anything else.' \\
\hline & Questioning & 'First listen very carefully, and then I will ask specific questions that I feel are appropriate.' \\
\hline \multirow[t]{3}{*}{ Non-verbal communication (6) } & Eye contact & $\begin{array}{l}\text { 'Typical things like the listening, eye contact, body language, and all of that kind of stuff is very } \\
\text { important.' }\end{array}$ \\
\hline & Body language & $\begin{array}{l}\text { 'I would say the whole thing about body language ... body language plays quite a role in determining } \\
\text { the state of mind of the client you work with.' }\end{array}$ \\
\hline & Non-verbal behaviour of counsellor & 'How to sit. So it's really the little things that make the difference for me ... how you carry yourself.' \\
\hline \multirow[t]{2}{*}{ Process knowledge (8) } & Helping Model & $\begin{array}{l}\text { 'I think it makes sense to work according to a specific model, otherwise you get confused and } \\
\text { struggle.' }\end{array}$ \\
\hline & Trauma counselling & 'In all honesty, the skills that I feel I know up 'til now are trauma debriefing skills.' \\
\hline \multirow[t]{2}{*}{ Referral (25) } & Appropriate referral & 'I would rather refer them, if they have had a big incident, to the psychologists.' \\
\hline & Maintain scope boundaries & $\begin{array}{l}\text { 'As an industrial psychologist, background of what I must or may or may not do in terms of the scope, } \\
\text { so if there is a case or problem ... I can refer it.' }\end{array}$ \\
\hline \multirow[t]{3}{*}{ Interpersonal skills (23) } & Reflecting & 'I'm going to reflect to make sure that I'm I hearing you correctly.' \\
\hline & Empathy & $\begin{array}{l}\text { 'And helping the individual with their personal problems, so there needs to be a certain sense of } \\
\text { empathy.' }\end{array}$ \\
\hline & Remain neutral and objective & $\begin{array}{l}\text { 'To avoid approaching a person or an organisation with preconceived ideas. ... He must make sure } \\
\text { that he does not assume; he does not just make conclusions; to guard against transference, to not } \\
\text { allow your own personal tastes or sense to influence your rational judgement.' }\end{array}$ \\
\hline
\end{tabular}

mentioned that this assists with the flow of the counselling process and that following a process or model keeps the process on track. Participants were of the opinion that trauma counselling is also a skill used during counselling: participants are required to provide trauma counselling after a traumatic incident has occurred.

\section{Referral}

Most of the participants mentioned referral as a counselling skill when they feel that there is another professional that would be better able to provide professional guidance for the client. Whenever participants felt that they lacked training on a specific issue, they would refer such a client. The participants reported that they take note of scope boundaries prohibiting them from counselling, which would then result in referral. Participants indicated that whenever counselling takes place, it is a requirement of counsellors to maintain boundaries. Maintaining boundaries as a counsellor refers to keeping a professional distance during the counselling process, in order to avoid a situation where a client becomes dependent on the counsellor. Whenever a client requires long-term counselling, such a client would also be referred.

\section{Interpersonal skills}

Participants regarded interpersonal skills as important in the counselling process. Participants reported that, during the counselling process, they would use reflection of feeling and of content as skill.

\section{Empathy}

Participants reported that, during counselling, it is often required to show empathy.

\section{Remain neutra}

Participants reported that remaining neutral in counselling is necessary in order for the counsellor to be empathetic but still maintain a professional distance.

\section{Remain objective}

The participants reported that, in order to remain objective, the counsellor is required to postpone forming judgement and conclusions about the client or the situation, and that remaining objective does not allow the counsellor to transfer their own personal beliefs or opinions onto the client. 


\begin{tabular}{|c|c|c|}
\hline Theme & Sub-theme & Response \\
\hline \multirow[t]{7}{*}{ Practical applications (21) } & Examinations & 'We also sat a practical examination with a trauma counsellor who evaluated us.' \\
\hline & Facilitating sessions & $\begin{array}{l}\text { 'I think we did a couple of practical sessions, but I don't think we were ever graded on them. ... } \\
\text { What they wanted to see was how far we were actually able to facilitate sessions with our normal } \\
\text { interviewing skills.' }\end{array}$ \\
\hline & Growth group training & 'We did a lot of growth groups in our M year, but it's more organisation-driven.' \\
\hline & Presentations & 'We had to do a presentation of the different paradigms, but it was not in depth.' \\
\hline & Relaxation techniques & 'The lecturer also ... showed us relaxation techniques that we had to practise on ourselves.' \\
\hline & Visit institutions & 'We also went to Weskoppies one day, so they also exposed us more to the clinical side.' \\
\hline & Case studies & $\begin{array}{l}\text { 'And then they gave us ... a scenario where you then had to had to identify, and you had to say how you } \\
\text { would deal with it, so it was part of what we did.' }\end{array}$ \\
\hline \multirow[t]{14}{*}{ Theory (48) } & Abnormal psychology & 'The abnormal psychology book ... part of our M degree, where we had to learn all the pathology.' \\
\hline & Basic counselling & 'I think it was just a background of what counselling is all about.' \\
\hline & Carkhuff's model & $\begin{array}{l}\text { 'I think it was the Carkhuff model of counselling. ... and we had to employ that model into our } \\
\text { counselling skills.' }\end{array}$ \\
\hline & Career guidance & $\begin{array}{l}\text { 'Career guidance in terms of psychometric testing and stuff, there's [sic] is a few career counselling } \\
\text { sessions with the training of the tests to give feedback on.' }\end{array}$ \\
\hline & Egan's model & 'We did Egan: the skilled helper.' \\
\hline & Imago therapy & 'We touched on the Imago therapy.' \\
\hline & Facilitation training & $\begin{array}{l}\text { 'There was also a whole section on facilitation skills, but that does not necessarily pertain to counselling } \\
\text { per se, although you know those skills might be relevant and applicable.' }\end{array}$ \\
\hline & Hypnosis & 'Where they demonstrated to us a light hypnosis.' \\
\hline & Ivey's micro-skills & 'That was the Carkhuff's model that was used, with Ivey's micro-skills.' \\
\hline & Music therapy & 'He showed us some music therapy which he used.' \\
\hline & Non-verbal communication & 'Non-verbal communication skills.' \\
\hline & Psychological theories & 'Got taught all the other theory ... you were more comfortable with ... all these psychology theories.' \\
\hline & Psychometric tests & 'Psychometrics ... a good connection with counselling, for instance, the 16PF.' \\
\hline & Trauma counselling & 'We had trauma counselling as a module; we had Advanced Counselling.' \\
\hline \multirow[t]{2}{*}{ Received no counselling training (3) } & & 'Not at all.' \\
\hline & Do not recall & 'If I have to be honest, I don't recall any theoretical work that we did.' \\
\hline
\end{tabular}

\section{Category 2: Academic training in counselling received by $\mathrm{I}-\mathrm{O}$ psychologists}

Five themes emerged in connection with counselling training. Participants received both practical and theoretical training. Table 2 shows the scope of training received by the participants.

The participants distinguished between practical and theoretical counselling training. Practical application concerned training in facilitating sessions by using interview skills and participation in growth groups. In addition, participants visited external institutions, such as psychiatric hospitals. Participants took part in role-play sessions, which provided them with the opportunity to practise their skills. Presentations and case studies regarding the different counselling paradigms were incorporated in some of the participants' practical training. Lastly, participants had to complete practical examinations.

With regard to theoretical training, specific reference was made to counselling models (such as Carkhuff, Egan, Imago and Ivey) and psychological theories (such as Frankl and Rogers). Other forms of practical training included basic counselling and music therapy, hypnosis and utilising different psychometric tests, which can be used to aid in career counselling. Lastly, trauma counselling and facilitation were also included in the training of some participants.
It should be noted that there were participants who mentioned that they do not particularly recall any theoretical training received. A few participants (3) reported that they did not receive any counselling training.

\section{Category 3: Evaluation of the efficiency of training received}

During the interviews, the participants commented on the efficiency of the counselling training they received during their formal academic training. This clearly emerged as a specific category, relating to sufficiency or insufficiency of training received (Table 3 ).

The participants who reported that the training they received was sufficient made specific reference to the adequacy of the theoretical part of the training. Some participants reported that not much focus on counselling training was given during their postgraduate training and that minimum training was received in this regard. Training that was received also lacked depth. Training insufficiency was attributed to the curriculum being outdated and, in some instances, the training experienced by participants being rushed.

\section{Category 4: Additional training received by I-O psychologists}

Participants reported that it was necessary to receive additional training, which is reported in Table 4. 
TABLE 3: Training sufficiency.

\begin{tabular}{|c|c|c|}
\hline Theme & Sub-theme & Response \\
\hline \multirow[t]{2}{*}{ Training sufficiency (7) } & Sufficient training & $\begin{array}{l}\text { 'I personally think we have been very well trained. I remember my Master's degree ... our ... } \\
\text { department really focused on the psychology part of industrial psychology. We received good training } \\
\text { in counselling.' }\end{array}$ \\
\hline & Competent facilitator & $\begin{array}{l}\text { 'The facilitator was excellent, and she knew what she was talking about and what she was doing in } \\
\text { that specific context.' }\end{array}$ \\
\hline \multirow[t]{5}{*}{ Training insufficiency (14) } & Lack of in-depth training & $\begin{array}{l}\text { 'I felt that counselling was not really delved into. ... Not a lot of time was put aside for just counselling; } \\
\ldots \text { we only had two or three classes of it, and they were compact. ... I think it was eight hours or } 12 \\
\text { hour-training and you had to just basically jump onto it and learn the skills.' }\end{array}$ \\
\hline & Insufficient practical exposure & 'I think the theory was substantial. I think there was enough theory, but the practical lacked.' \\
\hline & Minimal counselling training & 'Minimal real counselling training that I can remember, because it was so organisationally focused.' \\
\hline & Training was rushed & $\begin{array}{l}\text { 'I had to jump into it. I had to learn this in ... that period of time, as quickly as possible, and it felt, for } \\
\text { me, it was a little bit rushed.' }\end{array}$ \\
\hline & Outdated curriculum & 'I think our curriculum was extremely outdated.' \\
\hline
\end{tabular}

TABLE 4: Additional training received by I-O psychologists.

\begin{tabular}{|c|c|c|}
\hline Theme & Sub-theme & Response \\
\hline \multirow[t]{6}{*}{ Counselling approaches (8) } & Jung developmental group & $\begin{array}{l}\text { 'I am part of a Jung development group, which means I work under the supervision of clinical } \\
\text { psychologists and Jungian therapists.' }\end{array}$ \\
\hline & Mitchell model & $\begin{array}{l}\text { 'I was trained in the Mitchell model and, later on, that model was adapted to South African } \\
\text { conditions.' }\end{array}$ \\
\hline & $\begin{array}{l}\text { Logo therapy neuropsychology } \\
\text { course }\end{array}$ & $\begin{array}{l}\text { 'Because I joined the company ... extra course in psychotherapy, course in logo therapy, } \\
\text { neuropsychology.' }\end{array}$ \\
\hline & Psychotherapy course & 'An extra course in psychotherapy.' \\
\hline & $\begin{array}{l}\text { System psychodynamic } \\
\text { workshops }\end{array}$ & 'I have attended many system psychodynamic workshops.' \\
\hline & Rogerian training & 'I also received training in the Rogerian model of counselling - a person-centred counselling.' \\
\hline HIV- AIDS counselling (3) & & $\begin{array}{l}\text { 'A counselling process of Life Line SA in the Klerksdorp district, so I completed both those courses } \\
\text { there, and I also then ... acted as a counsellor volunteer at Life Line ... for about two to three years } \\
\text {... and during that time there was a lot of HIV and Aids-related phone calls ... received by the centre } \\
\text { and, subsequently, I had to brush up on those skills.' }\end{array}$ \\
\hline Psychometric assessment feedback (3) & & $\begin{array}{l}\text { 'A few psychometric tests like the } 16 \mathrm{PF}, \mathrm{MBTI} \text {... you got training in the testing, but also got training } \\
\text { on how to give feedback.' }\end{array}$ \\
\hline Trauma counselling (7) & & $\begin{array}{l}\text { 'That is why, when I became interested in trauma counselling, I did an additional course for three } \\
\text { days in trauma counselling.' }\end{array}$ \\
\hline \multirow[t]{2}{*}{ No additional training received (12) } & $\begin{array}{l}\text { Additional training never } \\
\text { required }\end{array}$ & 'I was never in that situation where I needed additional training.' \\
\hline & No personal interest & $\begin{array}{l}\text { 'Not at all, because, personally, I'm not interested in it. ... It is not for me at all, so I get very } \\
\text { uncomfortable when I work with problem situations.' }\end{array}$ \\
\hline
\end{tabular}

\section{Counselling approaches}

Participants reported that it was necessary to receive additional training in the counselling models and theories, such as the Mitchell model, neuropsychology, psychotherapy, logo therapy and Rogerian training. Other participants mentioned that they took part in a Jung developmental group, and others received additional training in a system dynamic workshop.

\section{HIV/AIDS counselling}

A few participants reported that they had received HIV and/ or AIDS counselling training.

\section{Psychometric assessment feedback}

Participants viewed training on psychometric assessments such as the Myers and Briggs Type Indicator and 16 Personality Factor questionnaire as counselling training, because they regard giving feedback on people's psychometric tests as counselling.

\section{Trauma counselling}

Participants reported that they had received additional training in trauma counselling.

\section{No additional training received}

Several comments were made by participants that indicated that they did not receive any additional training, because it was never a necessity. In addition, some participants reported that they did not have a personal interest in counselling and, therefore, additional training was never sought.

\section{Category 5: Recommendations made for the future training of I-O psychology students}

Participants were required to make recommendations regarding the training curriculum for future I-O psychology students. These are reported in Table 5.

According to the results, apart from receiving training in counselling skills, participants reported that additional training in emotional intelligence, conflict management as well as HIV and/or AIDS counselling would benefit I-O psychology students. It was reported that aspects to include in the postgraduate training of future students include: the different psychometric assessments and giving feedback, more in-depth counselling training, with an emphasis on psychology, and attention should be given to indigenously focused counselling, that is counselling specifically based 
TABLE 5: Recommendations made for the training curriculum of I-O psychology students.

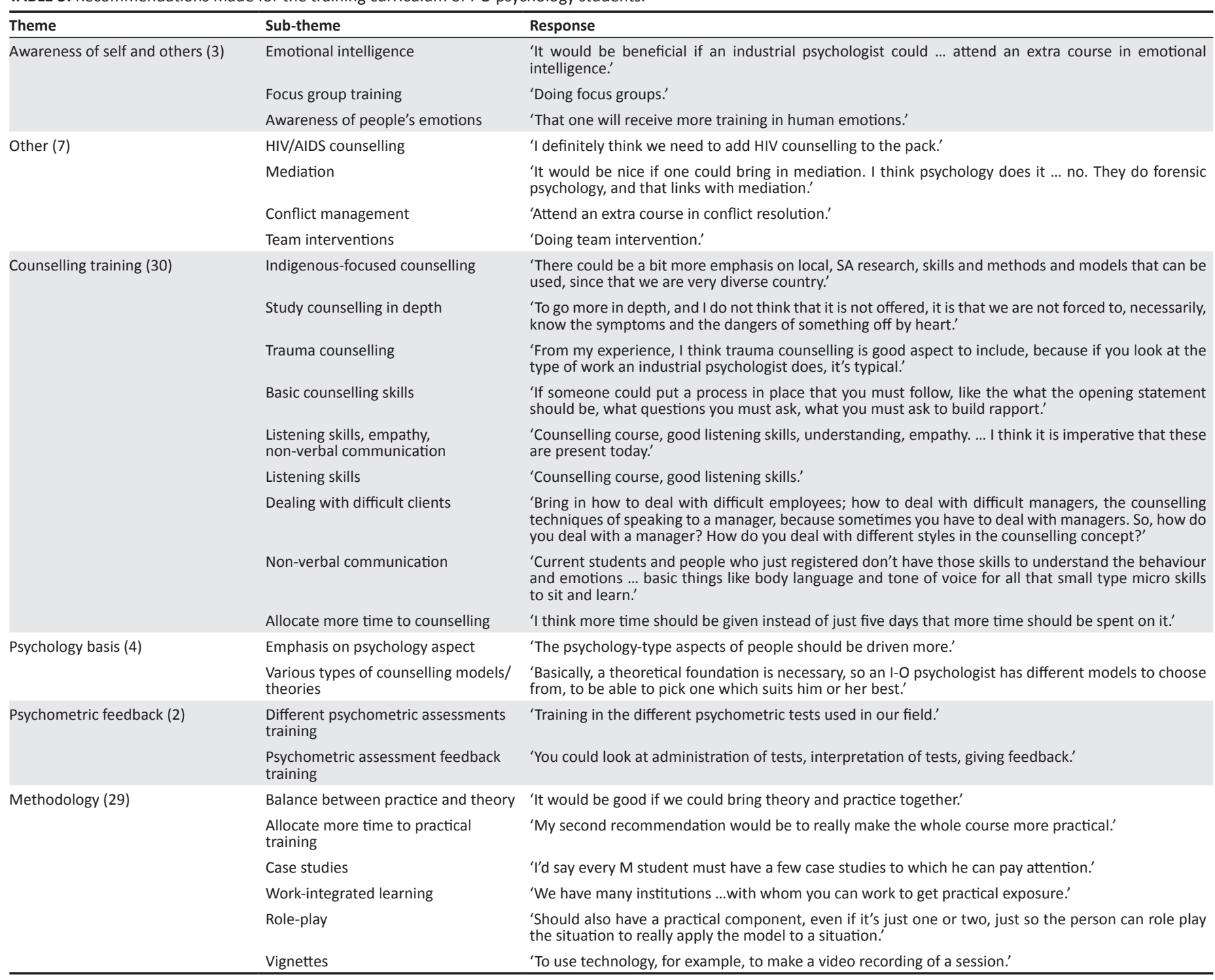

on South Africa's diverse culture. In addition, it was advised that trauma counselling be included in the training of future I-O psychologists. Training with regard to focus groups and team interventions was also recommended by participants, and it was mentioned once that it is recommended that students receive training in mediation. Participants reported that the curriculum should be more balanced in terms of theory and practical application, equally allocating time to the two applications. Participants mentioned that more time should be allocated to the practical training of students.

\section{Discussion}

The overall objective of this study was to explore whether I-O psychology students are adequately trained in preparation for their role as industrial psychologists. From the results, it was clear that although the I-O psychologists are familiar with the process of counselling, the results show that they mainly did not feel adequately prepared for their role as workplace counsellors. The participants made recommendations for the training of future industrial psychologists.
In the first category, participants reported that facilitation skills are necessary during a counselling situation, including building rapport with the client, a process that involves communication with clients in order to clarify the client's expectations of counselling. Facilitation, as defined by the participants, refers to assisting the client to reach a point where self-insight is obtained. In accordance with literature, counsellors often utilise facilitation skills (Prendiville 2012). A facilitator ensures that individuals make self-discoveries and serves to clarify issues, meanings and purposes (Schuman 2012). This finding is in accordance with Carkhuff (2008), who views attending as the skill that helps the counsellor enter the client's frame of reference and further stimulates the accurate communication and understanding of the client. I-O psychologists reported they made use of effective communication skills. Participants noted that these skills refer to the ability to listen actively to what the clients are saying as well as the ability to listen with insight. The results show that probing is a skill used during counselling by the participants. Literature indicates that probing plays an important part in the counselling process (Culley \& Bond 2004). Burnard (2013) states that only if effective 
communication is evident between the counsellor and client will the counsellor be able to assist the client; active listening enables the counsellor to respond to the client with empathy, genuineness and respect. Participants viewed non-verbal communication as a further skill used during counselling, which is in agreement with O'Toole (2008), who states that maintaining eye contact is viewed as an important aspect that guides active listening.

Another element that participants mentioned was that a counselling process or model is usually followed during the counselling process. Participants mentioned that this assists with the flow of the counselling process and keeps the process on track. According to Nelson-Jones (2012), counsellors follow a process or model because it is a structured framework with a basic step-by-step representation of the different goals and activities at developmental stages.

Participants were of the opinion that trauma counselling was also a skill used during counselling. This is in accordance with a study by Young, Koortzen and Oosthuizen (2012), who noted that I-O psychologists deal with trauma counselling situations.

Most of the participants mentioned referral as a counselling skill. The participants reported that referral would typically take place whenever there is another professional person who would be better suited to provide professional guidance to the client. Nelson-Jones (2012) is in support of this finding, stating that counsellors should make referrals to other counsellors if those counsellors possess skills that the original counsellor may not possess. The participants referred to the ability to maintain scope boundaries and the ability to maintain counsellor boundaries by keeping confidentiality and avoiding the creation of client dependency by maintaining professional distance. According to Seden (2005), it is the responsibility of counsellors to manage the boundaries between the self and others. Boundaries in this regard relate to confidentiality, contact, personal disclosure, time and place. Participants reported that maintaining professional distance is an important skill. This serves to keep the counsellor from becoming too emotionally involved with a client and allows them to maintain an objective stance (Culley \& Bond 2004).

Participants regard the effective use of interpersonal skills as eminent during the counselling process. This finding is in accordance with Carkhuff (2008), who states that the helping process takes place when interpersonal skills are applied in order to guide the client through their problems. Reflection or the means of reproducing or mirroring feelings is also one of the basic skills utilised by counsellors (Kuntze, Van der Molen \& Born 2009), as was also reported by the participants. Ivey (2013) states that it is the individual characteristics of a counsellor that will facilitate effective counselling. This relates to a theme that was derived from the results, namely the characteristics displayed by I-O psychologists during counselling. Participants reported that displaying empathy and having the ability to remain neutral and objective are key characteristics that should be displayed during counselling. With advanced and accurate empathy, the counsellor is able to provide an interpretation of the client's story, which is more distant from the client's frame of reference, but provides a sharper or more constructive view of the problem (Kuntze, Van der Molen \& Born 2009). Another essential characteristic of a counsellor is the ability to remain neutral whilst hearing the client's story and not judging them in any way (Schuman 2012). Although clients will need to experience some form of emotional closeness, which might be experienced in the form of empathy, the counsellor must strive to remain neutral by creating enough distance to remain in a helpful and objective space (Culley \& Bond 2004).

Notwithstanding the fact that students may take courses in I-O psychology at undergraduate level, it is at the postgraduate level that professional training in I-O psychology takes place (Carless \& Taylor 2006). Therefore, the second objective of the study was to determine what type of counselling training the I-O psychologists received at postgraduate level in order to train them as workplace counsellors. The psychologists reported that a component of their training consisted of practical application: for example, role-play sessions, which provided them with the opportunity to practise their skills. During the training, they had to make presentations regarding the different counselling paradigms. According to literature, an effective helping skills training programme includes the self-read-and-do method, lectures, behaviour modification and role-play (Rothmann 1996; Rothmann \& Van Aardt 2002). As part of the participants' practical training, they were also taught relaxation techniques. Finally, participants had to complete practical examinations concerning counselling.

The theoretical training that I-O psychologists received consisted of basic counselling training along with abnormal psychology training. Strümpfer (2007) mentions that the I-O psychologist should have a training background in counselling, whilst Watkins (2001) is of the opinion that I-O psychology students must receive training in different psychological theories. This correlates with findings in this study. Participants reported that training was received in the different psychological theories, such as the theory of Frankl and the theory of Rogers.

From the results of the study, it was found that although a small number of participants felt that their counselling training had been sufficient, the majority of the participants felt that the training received had been insufficient. The participants particularly reported the practical counselling component of the training to have been insufficient. This correlates with research findings suggesting that students prefer postgraduate training that integrates practical experience with academic learning (Kirby \& Hartstone 1998). According to Johnson and Kaslow (2014), the foundation of training for all professional psychology consists of both research and applied training. A revision of SIOP guidelines for postgraduate organisational psychology training (Society 
for Industrial and Organizational Psychology 1999:3) acknowledged that past guidelines were 'too focused on theory and that training programs need to have a dual emphasis on theory and practice'.

The results indicate that participants felt there had not been sufficient focus placed on counselling training and that as a result minimum counselling training had been received. The results of a study conducted by Carless and Taylor (2006) show that I-O psychology programmes tend to focus on the traditional issues in I-O psychology, such as job analysis and personnel assessment and selection, and that soft skills (such as interpersonal and counselling skills) tend to be either electives or not offered at all in the course. The results from this study mainly correlated with the findings of Carless and Taylor.

The aforementioned might serve as explanation as to why so many I-O psychologists felt the need to attend additional counselling training. Participants reported that additional training was sought for a diverse range of counselling approaches: HIV and/or AIDS counselling, psychometric assessments (and feedback) and trauma counselling.

The final objective of the study was to make recommendations for the future training of $\mathrm{I}-\mathrm{O}$ psychologists regarding counselling skills. The participants reported that I-O psychology students would benefit from receiving additional training in emotional intelligence courses, conflict management, as well as HIV and/or AIDS counselling, in addition to formal counselling training. Participants reported that future students should not only be trained in the different psychometric assessment tools, but also in how to provide feedback on the results. This is due to reports by participants that some psychometric assessment feedback can be considered to be a form of counselling. Additionally, participants reported that students should receive more in-depth counselling training, with an emphasis placed on the psychology aspect. Participants also felt that more attention should be placed on indigenous-focused counselling, specifically based on South Africa's diverse culture, along with providing students with training on the various counselling models and theories suitable for the South African context. In addition, it was advised that trauma counselling should be included in the training of future I-O psychologists. Some participants also reported that students could receive training for raising awareness of people's emotions. Training with regard to focus groups and team interventions was also recommended by participants.

Participants mostly reported that the curriculum should be more balanced in terms of theory and practical application and that a fair amount of time needs to be allocated to both aspects. This finding is in accordance with the Society for Industrial and Organizational Psychology (1999), who recommends that more time needs to be allocated to counselling. Participants also recommended that more time should be allocated to practical training. Having first-hand familiarity with the pitfalls, limitations and constraints of a technique is different from having developed a sound theoretical knowledge of the topic (Society for Industrial and Organizational Psychology 1999). Despite recognising the importance of including both science and practice in professional psychology training, these two activities or skill sets do not always co-exist as two ends of a continuum of training. Johnson and Kaslow (2014) place an emphasis on the integration of science and practice and mention that it is critical for the growth of the profession to distinguish training models from one another.

The participants made specific reference to listening skills and understanding the non-verbal communication of others as focus during counselling training. One participant mentioned that students should be equipped with skills to deal with difficult clients in counselling situations. Another participant said students should be trained on building empathy skills. This is in accordance with Kuntze, Van der Molen and Born (2009), who state that the micro-counselling method proves to be effective in training psychologists in communication skills.

\section{Limitations and recommendations}

No study is without limitations; the first limitation of the study relates to the fact that interviews were only conducted in two provinces. By including participants from other provinces, a more representative sample of industrial psychologists in South African could have been achieved. It could be that the level of experience in counselling influenced the answering of the questions. For example, some participants might have experienced difficulty in answering the questions relating to counselling if very little or no counselling experience was present. The study attempted to contribute to availableI-O psychology literature in terms of which counselling skills and competencies workplace counsellors are in need of. Consequently, it is recommended that future research should focus on the development of a training module that could be included in the curriculum of I-O psychology students in South Africa. As a result, it would also be important to consider how this training module would change the selection process for the postgraduate training of students, as more counsellingoriented programmes would need to be incorporated in training programmes.

\section{Implications for practice}

The study aimed to ultimately contribute to making I-O psychologists being better equipped to attend to the needs of the employee in the workplace in South Africa. McLeod and Henderson (2003) point out that workplace counselling offers the employer a service that is valued by employees, has the potential for savings by reducing sickness absence and takes pressure off managers. Through the availability of a constructive means of dealing with 'difficult' staff or situations, counselling can contribute to the organisation's reputation as a caring employer. 


\section{Conclusion}

In conclusion, referring to the initial question that guided this research, it seems that more should indeed be done in training the industrial-organisational psychologist as a workplace counsellor. The I-O psychologist stands central in the workplace and should be able to apply the principles of psychology in the workplace. It is essential that the I-O psychologist relies on sound theory based on a solid foundation rooted in psychology in order to effectively guide, identify problems and refer employees appropriately.

\section{Acknowledgements}

Recognition is hereby provided to the National Research Foundation (NRF) for funds provided to execute this research. However, any opinions, findings and conclusions and recommendations expressed in this material are those of the authors and therefore the NRF does not accept any liability therefore.

\section{Competing interests}

The authors declare that they have no competing interests that may have influenced this article in any way.

\section{Authors' contributions}

H.B. (North-West University) was the lead author and responsible for writing up the article and the data collection and partly for the data analysis. L.I.J. (North-West University) was the postgraduate supervisor of the lead author, assisted in secondary writing of literature review, was partly responsible for the data analysis and gave editorial input. L.B. (North-West University) was the associate supervisor of the lead author, trained the student in data analysis and assisted with the data analysis.

\section{References}

Azaroff, L.S., Champagne, N.J., Nobrega, S., Shetty, K. \& Punnett, L., 2010, 'Getting to know you: Occupational health researchers investigate employee assistance professionals' approaches to workplace stress', Journal of Workplace Behavioral Health 25(4), 296-319. http://dx.doi.org/10.1080/15555240.2010.520649

Barnard, G. \& Fourie, L., 2007, 'Exploring the roles and contributions of industria psychologists in South Africa against a multi-dimensional conceptual framework (part 2)', South African Journal of Industrial Psychology 33, 45-53.

Bergh, Z., 2011, Introduction to work psychology, Oxford University Press, Cape Town.

Botma, Y., Greeff, M., Mulaudzi, F.M. \& Wright, S.C.D., 2010, Research in health sciences, Pearson Education, Cape Town.

Burnard, P., 2013, Practical counselling and helping, Routledge, New York.

Byrne, Z.S., Hayes, T.L., Mort McPhail, S., Hakel, M.D., Cortina, J.M. \& McHenry, J.J., 2014, 'Educating industrial-organizational psychologists for science and practice: Where do we go from here?', Industrial and Organizational Psychology 7(1), 2-14. http://dx.doi.org/10.1111/iops.12095

Carducci, B.J., Deeds, W.C., Jones, W.J., Moretti, D.M., Reed, G.J., Saal, F.E. et al., 1987, 'Preparing undergraduate psychology students for careers in business', Teaching of Psychology 14(1), 16-20. http://dx.doi.org/10.1207/ s15328023top1401_3

Carkhuff, R.R., 2008, The art of helping in the 21st century, 8th edn., Human Resources Development Press, Inc., Amherst.

Carless, S. \& Taylor, P., 2006, 'Industrial and organisational psychology training in Australia and New Zealand', Australian Psychologist 41(2), 120-129. http://dx.doi. org/10.1080/00050060600575396

Cilliers, F., 2000, 'Facilitation skills for trainers', South African Journal of Industrial Psychology 26, 21-26. http://dx.doi.org/10.4102/sajip.v26i3.715

Creswell, J.W., 2009, Research design: Qualitative, quantitative, and mixed method approaches, 3rd edn., Sage Publications, Thousand Oaks, CA.
Cristiani, T.S. \& Cristiani, M.F., 1979, 'The application of counselling skills in the business and industrial setting', The Personnel and Guidance Journal 58, 166-169. $\mathrm{http}: / / \mathrm{dx}$.doi.org/10.1002/j.2164-4918.1979.tb00374.x

Culley, S. \& Bond, T., 2004, Integrative counselling skills in action, 2nd edn., Sage Publications, London.

De Vos, A.S., Strydom, H., Fouche, C.B. \& Delport, C.S.L., 2005, Research at grass roots: For the social sciences and human service professions, 3rd edn., Van Schaik Publishers, Pretoria.

Du Preez, J. \& Jorgensen, L.I., 2012, 'The evaluation of a helping skills training programme for intern-psychometrists', Journal of Psychology in Africa 22(1), 128-133.

Egan, G., 2009, The skilled helper: A problem-management and opportunitydevelopment approach to helping, 9th edn., Brooks/Cole, Pacific Grove.

Frost, N., 2011, Qualitative research methods in psychology: Combining core approaches, Oxford University Press, Berkshire.

Gray, D.E., 2004, Doing research in the real world, Sage Publications, London.

Ivey, A.E., 2013, Intentional interviewing and counselling: Facilitating client development in a multicultural society, 8th edn., Brooks/Cole, Pacific Grove.

Johnson, W.B. \& Kaslow, N.J., 2014, The oxford handbook of education and training in professional psychology, Oxford University Press, New York.

Kirby, N. \& Hartstone, M., 1998, 'Australian personnel managers and organisational psychology: An update', Australian Psychologist 33(2), 148-154. http://dx.doi. org/10.1080/00050069808257397

Kuntze, J., Van der Molen, H.T. \& Born, M.P., 2009, 'Increase in counselling communication skills after basic and advanced microskills training', British Journal of Educational Skills after basic and advanced microskills training', British Journal of Ed
Psychology 79, 175-188. http://dx.doi.org/10.1348/000709908X313758

Landy, F.J. \& Conte, J.M., 2004, Work in the 21st century: An introduction to industrial and organizational psychology, McGraw-Hill, New York.

Maree, K., 2007, First steps in research, 1st edn., Van Schaik Publishers, Pretoria.

McLeod, J., 2007, Counselling skill, Open University Press, Maidenhead.

McLeod, J. \& Henderson, M., 2003, 'Does workplace counselling work?', The British Journal of Psychiatry 182, 103-104. http://dx.doi.org/10.1192/bjp.182.2.103

McLeod, J. \& McLeod, J. (2011). Counselling skills. A practical guide for counsellors and helping professionals, 2nd edn., McGraw Hill Open University Press, New York.

Nelson-Jones, R., 2012, Introduction to counselling skills: Text and activities, 4th edn., Sage Publications, London.

Niewenhuis, J., 2010, 'Introducing qualitative research', in K. Maree (ed.), First steps in research, pp. 46-68, Van Schaik Publishers, Pretoria.

O'Toole, G., 2008, Communication: Core interpersonal skills for health professionals, 2nd edn., Elsevier.

Pienaar, Y. \& Roodt, G., 2001, 'Die teenswoordige en toekomstige rolle van bedryfsielkundiges in Suid-Afrika [The current and future roles of industria psychologists in South Africa]', Suid-Afrikaanse Tydskrif vir Bedryfsielkunde 27, 25-33.

Prendiville, P., 2012, Developing facilitation skills: A handbook for group facilitators, 3rd edn., Combat Poverty Agency, Dublin.

Rothmann, S., 1996, 'Die samestelling en evaluering van 'n groepfasiliteringskursus [The development and evaluation of a group facilitation course]', PhD thesis, Department of Industrial Psychology, Potchefstroom University for Christian Higher Education, South Africa.

Rothmann, S. \& Cilliers, F.V.N., 2007, 'Present challenges and some critical issues for research in industrial/organisational psychology in South Africa', South African Journa of Industrial Psychology 33(1), 8-17. http://dx.doi.org/10.4102/sajip.v33i1.262

Rothmann, S. \& Van Aardt, E.C., 2002, 'Die evaluering van 'n ontwikkelingsprogram in fasilitering vir studente in die gedragswetenskappe [The evaluation of development programme in facilitation for students in the behavioural sciences]', Suid-Afrikaanse Tydskrif vir Bedryfsielkunde 28(1), 37-43.

Schuman S., 2012, The IAF handbook of group facilitation: Best practices from the leading organization in facilitation, Jossey-Bass, San Francisco.

Seden, J., 2005, Counselling skills in social work practice, 2nd edn., Open University Press, Maidenhead.

Society for Industrial and Organizational Psychology, 1999, Guidelines for education and training at the doctoral level in Industrial-Organizational psychology, viewed 10 July 2013, from http://www.siop.org/PhDGuidelines98.aspx.

South Africa Department of Health, 2012, 'Health Professions Act, 1974: Draft discussion document. Regulations defining the scope of the profession of psychology', Government Gazette, 16 July 2012, Government Printer, Pretoria, South Africa.

Strümpfer, D.J.W., 2007, 'Lest we forget that industrial and organizational psychology is psychology', South African Journal of Industrial Psychology 33(1), 1-7.

Van Vuuren, L.J., 2006, 'Industrial psychology: Goodness of fit? Fit for goodness?', master's thesis, Department of Industrial Psychology and People Management, University of Johannesburg, South Africa.

Van Vuuren, L.J., 2010, 'Industrial psychology: Goodness of fit? Fit for goodness?', South African Journal of Industrial Psychology 36(2), 1-16. http://dx.doi. org/10.4102/sajip.v36i2.939

Wagner, C., Kawulich, B. B. \& Garner, M., 2012, Doing social research: A global context, McGraw-Hill Higher Education, Berkshire.

Watkins, M.L., 2001, 'Industrial psychology: An identity crisis and future direction', Journa of Industrial Psychology 27(4), 8-13. http://dx.doi.org/10.4102/sajip.v27i4.793

Young, M.E., 2009, Learning the art of helping: Building blocks and techniques, 4 th edn., Pearson, Upper Saddle River, NJ.

Young, M., Koortzen, P. \& Oosthuizen, R.M., 2012, 'Exploring the meaning of trauma in the South African Police Service: A systems psychodynamic perspective', South African Journal of Industrial Psychology 38(2), 183-194. 